\title{
STUDIES ON THE NUTRIENT AVAILABILITIES OF FEED INGREDIENTS IN ISRAELI CARP (Cyprinus carpio)
}

\author{
K. S. Chu, In K. Han', T. H. Won and B. C. Park \\ Dept. of Animal Sciences, College of Agriculture \\ Seoul National University, Suweon. 441-744, Korea
}

\begin{abstract}
Summary
Digestibilities of nutrients and energy are among the most important parameters to be determined in feed evaluation research. The apparent digestibility coefficients (ADC) of protein, total carbohydrate (TCHO), fat, energy and amino acids were determined for 14 common feed ingredients using chromic oxide as external indicator with Israeli carp (Cyprinus carpio). The ingredients tested were; corn, corn starch, gelatinized starch, wheat middling, wheat grade inferior, corn gluten meal, rapeseed meal (solvent extracted), soybean meal (solvent extracted), blood meal (drum dried), feather meal(hydrolyzed), file fish meal (flame dried), sardine fish meal (steam dried), sardine fish meal (flame dried) and brewers yeast (dehydrated).

The overall ADC values were high in Israeli carp showing high capacity to digest their feed ingredients irrespective of plant or animal sources. In addition the ADC of plant protein was high enough to support the successful supplementation of fish meal with other plant proteins.
\end{abstract}

(Key Words: Nutrient Availabilty, Feed Ingredients, Israeli Carp).

\section{Introduction}

Though the history of inland aquaculture in Korea is short, its production is expanding year by year and it is becoming an important forming industry in Korea. However, in contrast to this rapid development in inland aquaculture, there have been very little progresses in the field of fish nutrition.

Many investigations have been concerned with the problems of digestibility measurements on fishes, and extensive data on factors affecting digestibility. However, systematic examinations on the numerous individual feed ingredients for a given fish species, especially in Israeli carp (Cyprinus carpio), are lacking because of complicated methodological procedures.

Concerning the methods used for the determination of nutrients digestibilities there have been many improvements to overcome difficulties such as nutrient leaching in the water. The earliest method was direct, and involved laborious and time-consuming water filtration techniques that

\footnotetext{
${ }^{1}$ Adress reprint request to Dr. In K. Han, Dept. of Animal Sciences, College of Agriculture, Seoul National University, Suweon 441-744, Korea.

Received March 13, 1991

Accepted June 10, 1991
}

required collection, measurement, and analysis of all egesta and excretions (Migita et al., 1937: Tunisonet et al., 1942). Also an indirect method successfully applied to agricultural animals has been used with several species of fish (Nose, 1960a, b; Hastings, 1969; Smith and Lovell, 19 71, 1973; Windell et al., 1978). However, despite the fact that the chromic oxide method is convenient and has been widely used for studies on single ingredients and formulated fish feeds, fecal collection methods pose a serious technical problem related to accuracy of reported results for both indirect and direct methods (Nose, 1967; Smith and Lovell, 1971; Furukawa, 1976). Because fecal exposure to water results in leaching of nutrients into the water, a number of fecal collection methods have been developed such as dissection (Kitamikado et al., 1964; Hastings, 1967), and sack (Furukawa, 1976), abdominal pressure (Inaba et al., 1962; Singh and Nose, 1967), metabolic chambers (Smith, 1971, 1976) and settling of feces (Cho and Slinger, 1979). Fecal collection in this experiment was made using settling column and digestibility trial was followed by the procedure previously reported by Cho and Slinger (1979).

The objectives of this study were to examine the availability of some nutrients in major fish 
CHU ET AL.

TABLE 1. EXPERIMENTAL DESIGN

\begin{tabular}{|c|c|c|c|}
\hline Treatment & $\begin{array}{l}\text { International } \\
\text { feed number }\end{array}$ & $\begin{array}{l}\text { No. of } \\
\text { replication }\end{array}$ & $\begin{array}{l}\text { No. of fish } \\
\text { per replication }\end{array}$ \\
\hline Reference diet & & 5 & 15 \\
\hline \multicolumn{4}{|l|}{ Carbohydrates } \\
\hline Corn & $4-02-861$ & 5 & 15 \\
\hline Corn starch & 4-02-889 & 5 & 15 \\
\hline Gelatinized starch & $4-23-957$ & 5 & 15 \\
\hline Wheat, middling & $4-05-205$ & 5 & 15 \\
\hline Wheat, grade inferior & $4-05-272$ & 5 & 15 \\
\hline \multicolumn{4}{|l|}{ Plant proteins } \\
\hline Corn gluten meal & $5-09-318$ & 5 & 15 \\
\hline $\begin{array}{l}\text { Rapeseed meal } \\
\quad \text { (solvent extracted) }\end{array}$ & $5-03-871$ & 5 & 15 \\
\hline $\begin{array}{l}\text { Soybean meal } \\
\quad \text { (solvent extracted) }\end{array}$ & $5-20-637$ & 5 & 15 \\
\hline \multicolumn{4}{|l|}{ Animal proteins } \\
\hline Blood meal (drum dried) & $5-00-380$ & 5 & 15 \\
\hline Feather meal (hydrolyzed) & $5-03-795$ & 5 & 15 \\
\hline $\begin{array}{l}\text { Fish meal, file } \\
\text { (flame dried) }\end{array}$ & $5-06-676$ & 5 & 15 \\
\hline $\begin{array}{l}\text { Fish meal, sardine } \\
\text { (steam dried) }\end{array}$ & $5-08-986$ & 5 & 15 \\
\hline $\begin{array}{l}\text { Fish meal, sardine } \\
\text { (flame dried) }\end{array}$ & $5-08-986$ & 5 & 15 \\
\hline \multicolumn{4}{|l|}{ Supplement } \\
\hline $\begin{array}{r}\text { Yeast, brewers } \\
\text { (dehydrated) }\end{array}$ & $7-05-527$ & 5 & 15 \\
\hline
\end{tabular}

feed ingredients and to aid basic knowledges to the field of fish nutrition. In the present study an attempt was conducted to estimate the digestible energy (DE) and nutrients availabilities of 14 common feed ingredients currently utilized in commercial carp feed.

\section{Materials and Methods}

\section{Experimental design}

To evaluate the nutrient availabilities of major feed ingredients commonly used in fish feed industry, 14 ingredients were chosen as listed in table 1 . A practical diet similar to the commercial one was used as reference diet. Experimental design is presented in table 1 .

The reference diet was formulated to contain $40 \%$ crude protein and $3,300 \mathrm{kcal} / \mathrm{kg}$ of digestible
TABLE 2. FORMULA OF THE REFERENCE DIET (\%)

\begin{tabular}{lc}
\hline Ingredients & percentage \\
\hline Fish meal & 50 \\
Soybean meal & 10 \\
$\quad$ (solvent extracted) & \\
Wheat middlings & 29.8 \\
Yeast & 2 \\
Vitamins & 2 \\
Minerals & 2 \\
Lysine & 0.1 \\
Methionine & 0.1 \\
Fish oil & 3 \\
Chromic oxide & 1 \\
\hline Total & 100 \\
\hline
\end{tabular}


energy. One percent of chromic oxide was added to evaluate the digestion coefficients. The formula and chemical composition of the reference diet is appeared in table 2.

The experimental diet was made by mixing $70 \%$ of reference diet and $30 \%$ of testing ingre- dient as shown in table 3 . All the ingredients used were ground to be finer than 50 mesh. The experimental diets were steam-pelletized to 3.2 mm size using a commercial pellet mill (California Pellet Mill).

TABLE 3. REFERENCE AND TEST DIETS FOR DIGESTIBILITY STUDIES (\%)

\begin{tabular}{lcc}
\hline & Reference diet (I) & Experimental diet (II) \\
\hline Test ingredient (III) & 0 & 29.7 \\
Reference diet & 99.0 & 69.3 \\
$\mathrm{Cr}_{2} \mathrm{O}_{3}$ & 1.0 & 1.0 \\
\hline
\end{tabular}

Experimental animal and system

Fish used in the experiment were Israeli carp (Cyprinus carpio) weighing approximately $300 \mathrm{~g}$. A total of 450 fish of similar body weight was used in the experiment. Among the total of 34 tanks made for metabolic trial, 30 tanks with 15 fish were used. The bottom of the tank was sloped and connected to the drainpipe.

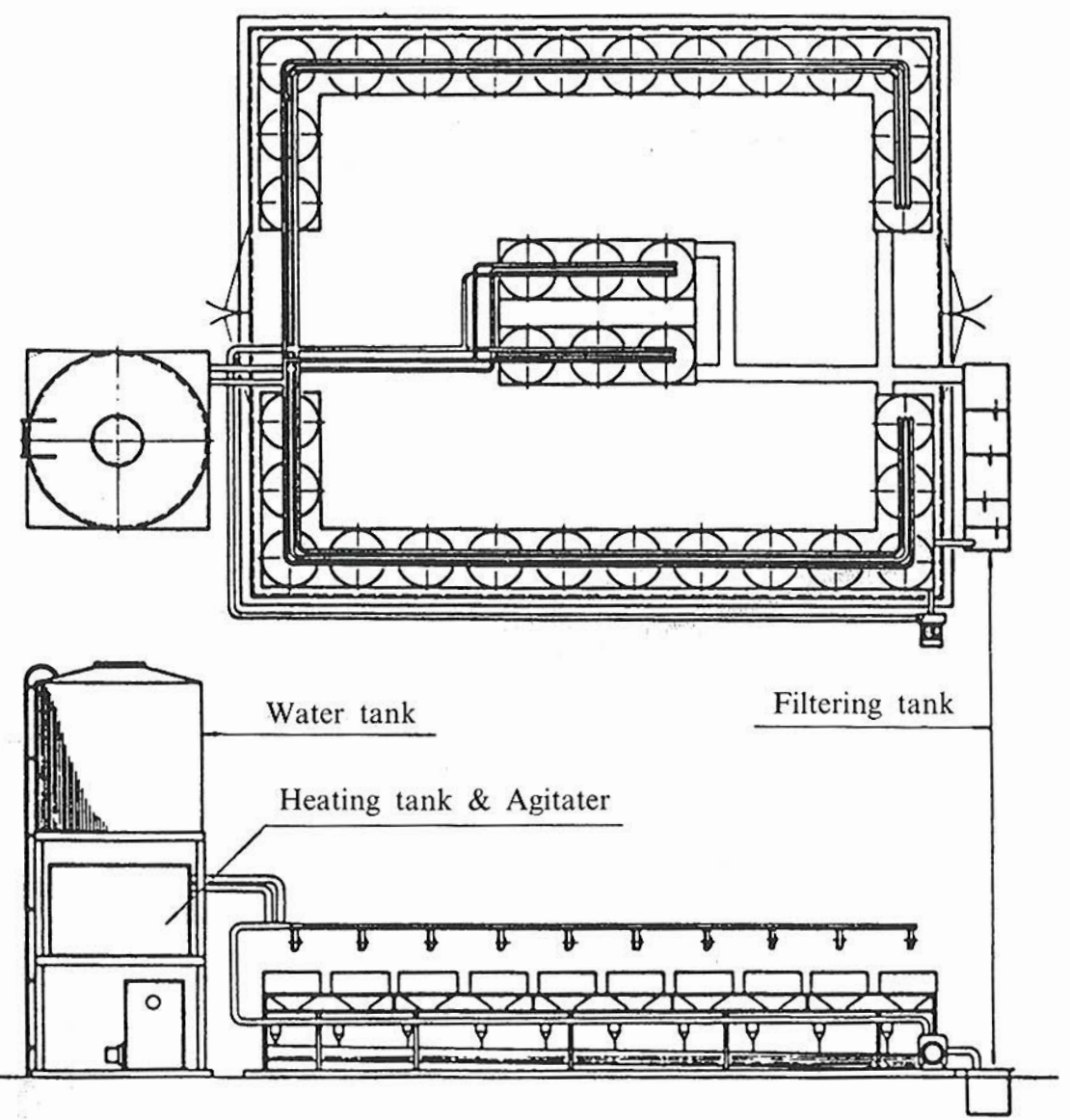

Figure 1. Experimental feeding and digestibility trial-system 

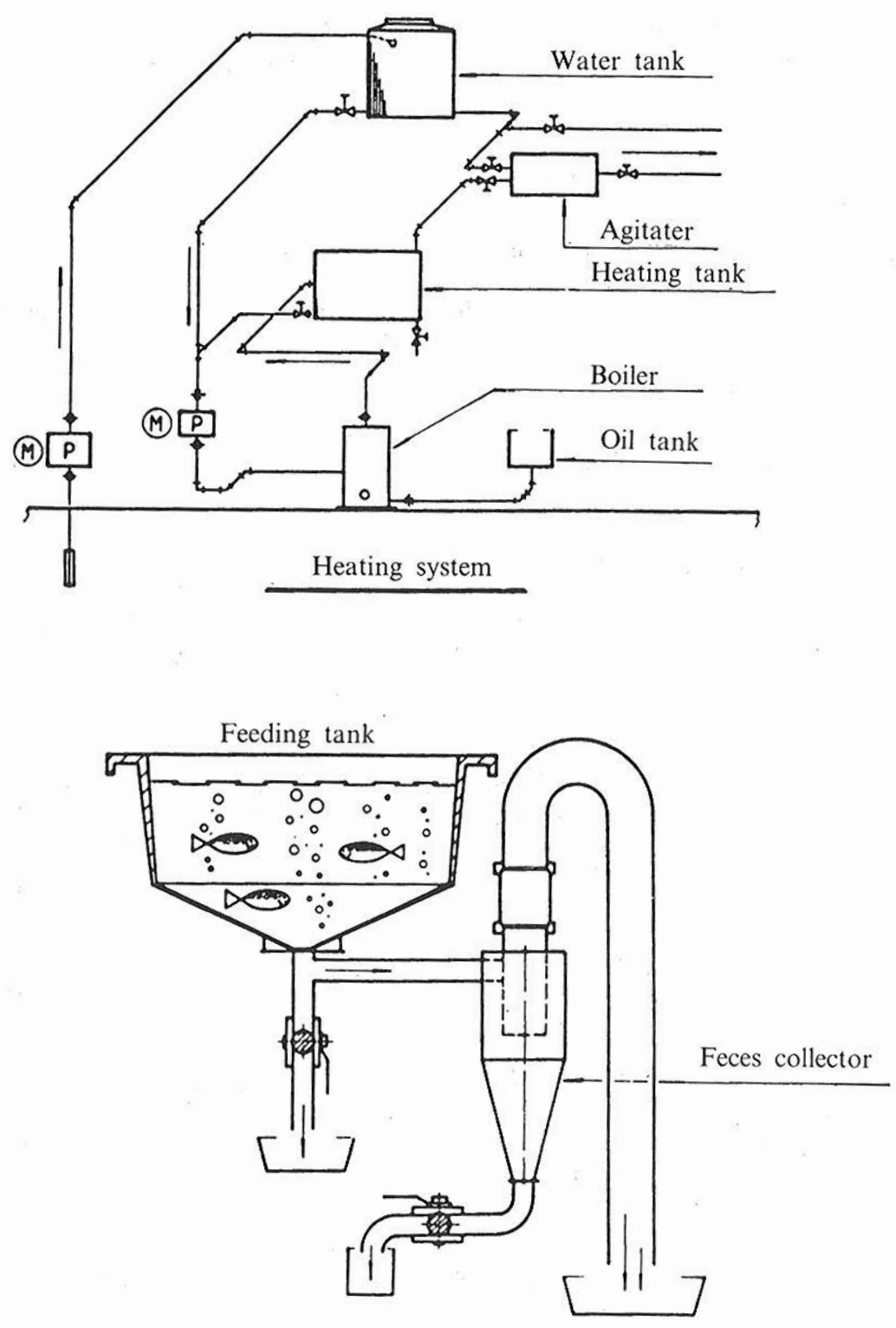

Figure 1. Experimental feeding and digestibility trial-system(continued)

In one side of the drainpipe feces collector using settling column was attached. The feces trapped in the bottom of the feces collector were maintained in quiet water until the daily morning collection. The structure of the experimental feeding and digestibility trial tank was modified from Guelph System (Cho and Slinger, 1979) and illustrated in figure 1.

The water content of each tank was fixed to be $100 l$. The water temperature was maintained to be $24 \pm 1^{\circ} \mathrm{C}$ using heating system and circulating pipes for the experimental period. Each tank was aerated continuously and the flow rate was regulated to be $0.8 \mathrm{l} / \mathrm{min}$.

Throughout the experimental period the $\mathrm{pH}$ was maintained 6.5 , dissolved oxygen (DO) 4.5 $-5.3 \mathrm{mg} / l$, ammonia concentration $1-3 \mathrm{mg} / \mathrm{kg}$ and nitrate concentration $0.3-0.5 \mathrm{mg} / \mathrm{kg}$. 


\section{NUTRIENT AVAILABILITY IN ISRAELI CARP}

Feeding regimen and feces collection

The fish were adapted to both the tanks and the feeding regimen for a week before collection of feces began. The fish were fed from 09:00 through 11:00 h, 14:00 through 16:00 h ad libitum and the diets were offered only as long as the fish were actively feeding to avoid wastage. One hour after the last meal, the drainpipe and the bottom of the tank were cleaned to remove feed residues and feces from the system. One third to a half of the water in the tank was drained out to ensure that the cleaning procedure was completed. At $08: 30 \mathrm{~h}$ the following day, the settled feces and surrounding water were gently withdrawn from the base of the feces collector into a sampling dish (Cho et al., 1974). These feces were free of uneaten feed particles and considered to be a representative sample of the feces produced throughout the $24 \mathrm{~h}$ period. Immediately after collection of the feces, the fish were fed again as normal for the next day's sampling. This procedure was repeated for 5 days and the samples were pooled. When the feces were sampled, they were dried at $60^{\circ} \mathrm{C}$ in a drying oven for 72 hours and ground for the determination of chromic oxide concentration, nutrient analysis and estimation of energy values.

\section{Chemical analysis}

All the proximate analyses of experimental diets and feces were conducted by AOAC (1990) methods. The amino acid contents were analyzed by an automatic amino acid analyzer (LKB, Model 4150-alpha).

The energy values were measured using an oxygen adiabatic bomb calorimeter (Parr, Model 1241) and the chromic oxide concentrations were determined by an atomic absorption spectrophotometer (Shimadzu, Model AA625).

\section{Calculation}

The apparent digestibility coefficients (ADS) of components of test ingredients were calculated using the following formulae (Nose, 1960a, b; Hastings, 1966, 1969; Smith and Lovell, 1971; Wilson et al., 1981)

$\mathrm{DMD}($ dry matter digestibility $)=100-$ $(\mathrm{Dcr} / \mathrm{Fcr}) \times 100$

$\mathrm{ADC}$ of reference or experimental diet $=$
$100-(\mathrm{F} / \mathrm{D} \times \mathrm{Dcr} / \mathrm{Fcr}) \times 100$

$\mathrm{ADC}$ of test ingredient $=(\mathrm{ADC}$ of experimental diet $-0.7 \mathrm{ADC}$ of reference diet) $/ 0.3$

Where

$$
\begin{aligned}
& F=\% \text { nutrient in feces } \\
& D=\% \text { nutrient in diet } \\
& F c r=\% \text { chromic oxide in feces } \\
& \text { Dcr }=\% \text { chromic oxide in diet }
\end{aligned}
$$

\section{Results}

In table 4 and 5 the results of proximate analysis and amino acid composition of tested ingredients are recorded. The values of proximate analysis and amino acid contents were much in accordance with the values reported by NRC (1981, 1983) and the Korean tables of Feed Composition (Han et al., 1982). In table 6, The DMD (dry matter digestibility), the ADC of protein, total carbohydrates (TCHO), fat, energy and $\mathrm{DE}$ (digestible energy) content of tested ingredients are shown. In table 7 the ADC values of amino acids of tested ingredients are listed.

The overall ADC values appeared to be high in Israeli carp. The DE value of corn for carp was revealed to be $3,360 \mathrm{kcal} / \mathrm{kg}$ when $75.1 \%$ of its energy content was digested. The DMD and $\mathrm{ADC}$ of $\mathrm{TCHO}$ were $71.0 \%$ and $89.8 \%$, respectively.

The DMD of corn-starch and gelatinized starch were 70.3 and $72.3 \%$, respectively. Though gelatinized starch showed little higher digestibilities in carbohydrate and energy than corn starch due to improvement by processing, the ADC of TCHO of both starch was high enough (98 and $11.2 .5 \%$ ) suggesting that they might be used as a good energy source in the ration of Israeli carp.

The ADC of TCHO of wheat was $94.5 \%$ for wheat middling and $93.7 \%$ for wheat grade inferior. It was an interesting finding that most nutrients ADC of wheat grade inferior resulted in not lower than that of wheat middling except energy. However, the amino acids ADC of wheat middling were superior $(78.8 \pm 15.0 \%)$ to that of wheat grade inferior $(51.2 \pm 13.0 \%)$.

The protein ADC of corn gluten meal (CGM) showed a high value $(93.9 \%)$, the same trend showed in amino acids ADC $(89.7 \pm 14.4 \%)$. CGM may be used as a good protein source in the ration of carp. The DMD of CGM was $78.4 \%$. The ADC of energy was $90.8 \%$. 
CHU ET AL.

TABLE 4. PROXIMATE ANALYSIS OF THE TESTED INGREDIENTS (\%, DM BASIS)

\begin{tabular}{|c|c|c|c|c|c|c|c|c|}
\hline Treatment & $\begin{array}{l}\text { Gross energy } \\
\text { (kcal } / \mathrm{kg})\end{array}$ & Moisture & $\begin{array}{l}\text { Crude } \\
\text { protein }\end{array}$ & $\begin{array}{c}\text { Crude } \\
\text { fat }\end{array}$ & $\begin{array}{l}\text { Crude } \\
\text { fiber }\end{array}$ & $\begin{array}{l}\text { Crude } \\
\text { ash }\end{array}$ & $\mathrm{Ca}$ & $\mathrm{P}$ \\
\hline Reference diet & 4,232 & 8.44 & 43.42 & 4.55 & 2.84 & 10.84 & 3.59 & 2.23 \\
\hline \multicolumn{9}{|l|}{ Carbohydrates feeds } \\
\hline Corn & 4,480 & 10.91 & 8.50 & 3.70 & 2.90 & 1.80 & 1.51 & 0.68 \\
\hline Corn starch & 3,624 & 11.78 & 1.43 & 0.66 & 1.23 & 0.07 & 1.80 & 0.15 \\
\hline Gelatinized starch & 3,681 & 8.77 & 0.74 & 1.00 & 0.73 & 0.14 & 1.97 & 0.19 \\
\hline Wheat, middling & 3,985 & 12.88 & 16.11 & 2.86 & 3.35 & 2.39 & 1.24 & 0.40 \\
\hline Wheat, grade inferior & 3,896 & 11.99 & 13.19 & 2.88 & 1.87 & 1.03 & 1.22 & 0.33 \\
\hline \multicolumn{9}{|l|}{ Plant proteins } \\
\hline Corn gluten meal & 5,177 & 10.19 & 59.43 & 0.88 & 1.20 & 1.35 & 0.10 & 0.44 \\
\hline $\begin{array}{l}\text { Rapeseed meal } \\
\text { (solvent extracted) }\end{array}$ & 4,096 & 9.47 & 37.47 & 1.74 & 9.15 & 8.96 & 1.75 & 1.08 \\
\hline $\begin{array}{l}\text { Soybean meal } \\
\quad \text { (solvent extracted) }\end{array}$ & 4,204 & 11.06 & 44.72 & 1.91 & 6.48 & 5.97 & 1.31 & 0.71 \\
\hline \multicolumn{9}{|l|}{ Animal proteins } \\
\hline Blood meal (drum dried) & 5,086 & 11.82 & 87.96 & 1.62 & 2.03 & 2.23 & 1.77 & 0.33 \\
\hline Feather meal (hydrolyzed) & 4,930 & 12.77 & 81.26 & 0.74 & 3.20 & 2.44 & 1.90 & 0.36 \\
\hline $\begin{array}{l}\text { Fish meal, file } \\
\text { (flame dried) }\end{array}$ & 3,768 & 7.85 & 52.06 & 6.09 & 2.06 & 26.64 & 10.13 & 4.86 \\
\hline $\begin{array}{l}\text { Fish meal, sardine } \\
\text { (steam dried) }\end{array}$ & 4,479 & 7.30 & 63.01 & 7.75 & 3.08 & 16.87 & 6.14 & 2.38 \\
\hline $\begin{array}{l}\text { Fish meal, sardine } \\
\text { (flame dried) }\end{array}$ & 4,604 & 9.24 & 64.72 & 5.72 & 2.10 & 13.67 & 5.25 & 2.37 \\
\hline \multicolumn{9}{|l|}{ Supplement } \\
\hline $\begin{array}{r}\text { Yeast, brewers } \\
\text { (dehydrated) }\end{array}$ & 4,335 & 10.24 & 48.64 & 2.12 & 5.27 & 6.07 & 2.02 & 0.86 \\
\hline
\end{tabular}

Protein and energy ADC of rapeseed meal (solvent extracted) were 89.6 and $57.7 \%$, respectively. The amino acids ADC of rapeseed meal were a little lower $(75.0 \pm 8.38 \%)$ than that of other plant protein feeds tested (table 7). The DMD of soybean meal (solvent extracted) was $45.3 \%$. Its $\mathrm{ADC}$ was $80.5 \%$ in protein, $46.1 \%$ in $\mathrm{TCHO}$ and $64.7 \%$ in energy. The mean amino acid digestibility was $84.3 \pm 7.04 \%$.

The DMD of blood meal was $66.3 \%$. Its protein $\mathrm{ADC}$ was lowest $(54.6 \%)$ compared to other animal protein ingredients tested. Its mean amino acids ADC were somewhat poorer being $26.5 \pm 15.8 \%$ digested. The energy content of blood meal was poorly digestible $(60.2 \%)$. Its DE value was $3,060 \mathrm{kcal} / \mathrm{kg}$.

Feather meal showed relatively higher ADC. Among its protein contents $87.1 \%$ was digested.
But contrary to this result only $22.5 \pm 12.3 \%$ of its amino acids contents were digested. A explanation was not made for the low amino acid digestibility of $22.5 \pm 12.3 \%$ compared to higher value of $82.1 \%$ of protein digestibility. The ADC of energy was moderate $(77.4 \%)$ and its DE value was $3,816 \mathrm{kcal} / \mathrm{kg}$.

The DMD of fish meal was $35.5 \%, 70.9 \%$ and $83.1 \%$ in file fish meal (flame dried), sardine fish meal (steam dried) and sardine fish meal (flame dried), respectively. The ADC of protein of file fish meal was much lower (68.4\%) than that of sardine fish meal (93.4 and $99.1 \%$ ). Also the ADC of energy was low in file fish meal $(63.8 \%)$ whereas high in sardine fish meal $(83.9$ and $95.0 \%$ ). The DE values were $2,403 \mathrm{kcal} / \mathrm{kg}$ in file fish meal (flame dried), $3,756 \mathrm{kcal} / \mathrm{kg}$ in sardine fish meal (steam dried) and 4,376 kcal $/ \mathrm{kg}$ 


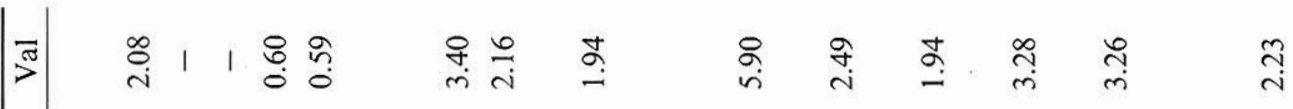

氙 $\stackrel{\infty}{\stackrel{0}{-} 1}$ 1

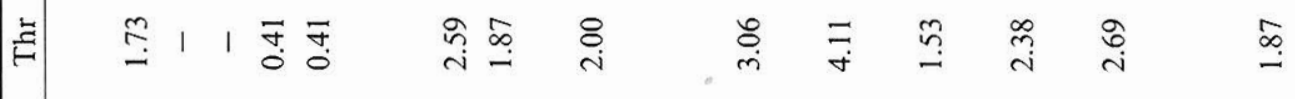

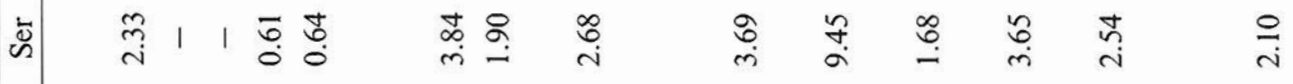

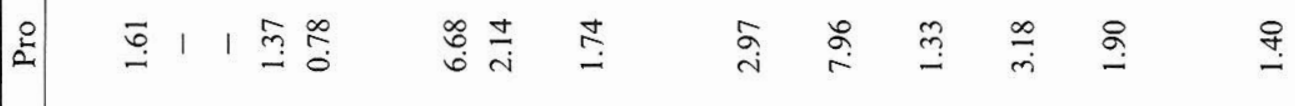

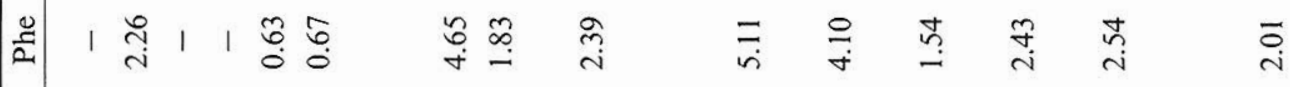

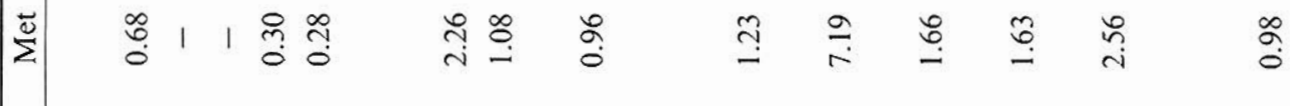

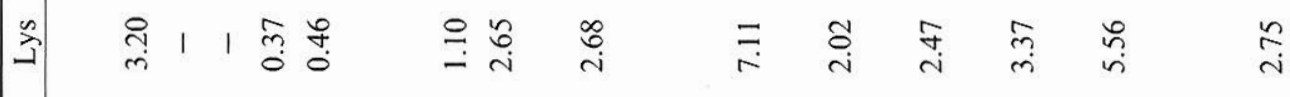

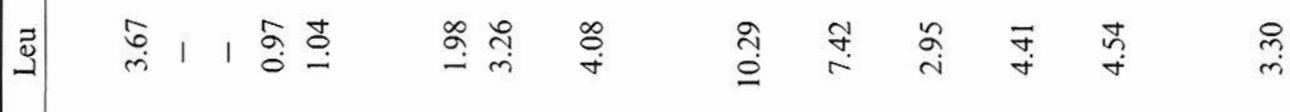

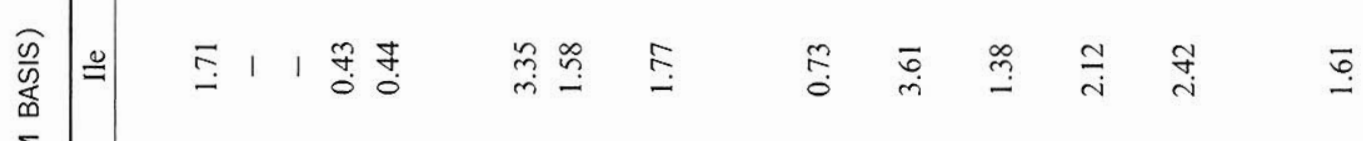

do

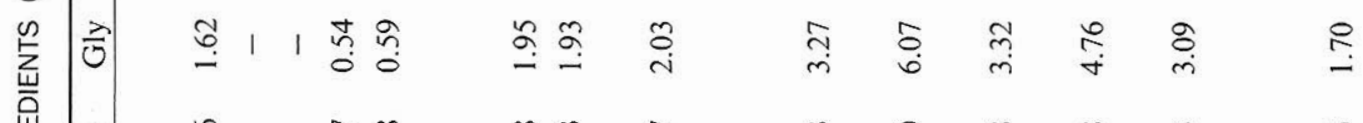

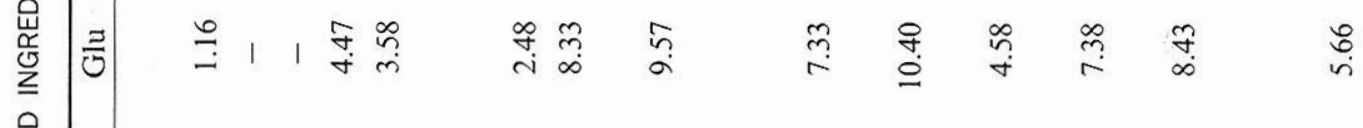

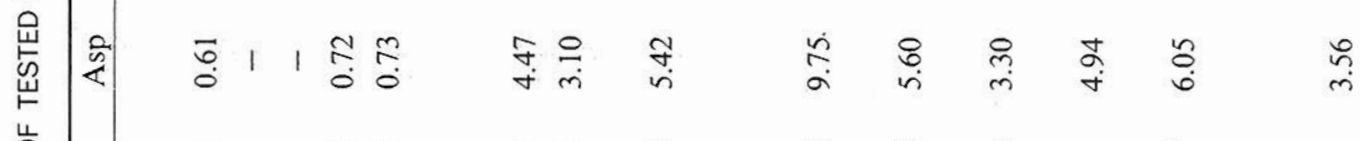

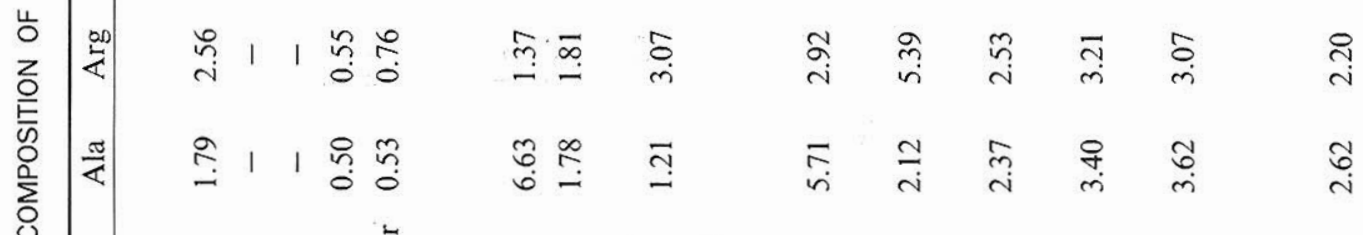

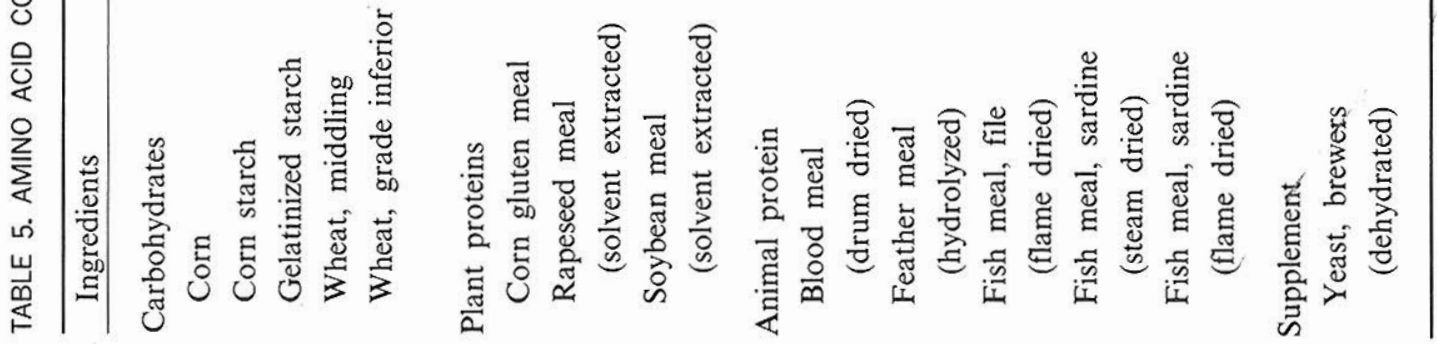


CHU ET AL.

TABLE 6. APPARENT DIGESTIBILITY COEFFICIENTS OF TESTED INGREDIENTS ( $\%$, DM BASIS)

\begin{tabular}{|c|c|c|c|c|c|c|c|}
\hline & DMD & Protein & TCHO & Fat & Energy & $\begin{array}{c}\mathrm{DE} \\
(\mathrm{kcal} / \mathrm{kg})\end{array}$ & $\begin{array}{c}\mathrm{DE} \\
(\mathrm{MJ} / \mathrm{kg})\end{array}$ \\
\hline Reference diet & 69.0 & 79.8 & 78.0 & 81.3 & 73.4 & 3,107 & 13.0 \\
\hline \multicolumn{8}{|l|}{ Carbohydrates } \\
\hline Corn & 71.0 & - & 89.8 & - & 75.1 & 3,364 & 14.1 \\
\hline Corn starch & 70.3 & - & 98.0 & - & 62.1 & 2,250 & 9.4 \\
\hline Gelatinized starch & 72.3 & - & 112.5 & - & 82.0 & 2,979 & 12.5 \\
\hline Wheat, middling & 71.2 & - & 94.5 & - & 65.9 & 2,568 & 10.8 \\
\hline Wheat, grade inferior & 76.3 & - & 93.7 & - & 81.2 & 3,235 & 13.8 \\
\hline \multicolumn{8}{|l|}{ Plant proteins } \\
\hline Corn gluten meal & 78.4 & 93.9 & 88.6 & - & 90.8 & 4,699 & 19.7 \\
\hline $\begin{array}{l}\text { Rapeseed meal } \\
\text { (solvent extracted) }\end{array}$ & 53.0 & 89.6 & 37.0 & - & 57.7 & 2,363 & 9.9 \\
\hline $\begin{array}{l}\text { Soybean meal } \\
\quad \text { (solvent extracted) }\end{array}$ & 45.3 & 80.5 & 46.1 & - & 64.7 & 2,721 & 11.4 \\
\hline \multicolumn{8}{|l|}{ Animal proteins } \\
\hline Blood meal (drum dried) & 66.3 & 54.6 & - & - & 60.2 & 3,060 & 12.8 \\
\hline Feather meal (hydrolyzed) & 86.1 & 87.1 & - & - & 77.4 & 3,816 & 16.0 \\
\hline $\begin{array}{l}\text { Fish meal, file } \\
\text { (flame dried) }\end{array}$ & 35.5 & 68.4 & - & - & 63.8 & 2,403 & 10.1 \\
\hline $\begin{array}{l}\text { Fish meal, sardine } \\
\text { (steam dried) }\end{array}$ & 70.9 & 93.4 & - & - & 83.9 & 3,756 & 15.7 \\
\hline $\begin{array}{l}\text { Fish meal, sardine } \\
\text { (flame dried) }\end{array}$ & 83.1 & 99.1 & - & - & 95.0 & 4,376 & 18.3 \\
\hline \multicolumn{8}{|l|}{ Supplement } \\
\hline $\begin{array}{r}\text { Yeast, brewers } \\
\text { (dehydrated) }\end{array}$ & 77.5 & 86.8 & 72.4 & 67.1 & 83.7 & 3,626 & 15.2 \\
\hline
\end{tabular}

in sardine fish meal (flame dried). Though the overall $\mathrm{ADC}$ values of file fish meal (flame dried) were extremely low, its amino acid ADC was high enough $(89.4 \pm 11.1 \%)$ as compared to the other fish meals $(93.7 \pm 6.8$ and $89.7 \pm 1.0 \%)$.

The DMD of brewers yeast was $77.5 \%$. Its $\mathrm{ADC}$ was $86.8 \%$ in protein, $72.4 \%$ in $\mathrm{TCHO}$ and $83.7 \%$ in energy. The DE value was $3,826 \mathrm{kcal} / \mathrm{kg}$.

\section{Discussion}

As indicated by these results the overall ADC of tested ingredients showed relatively high in Israeli carp (table 6 and 7). That is, compared with other cultured fish species such as rainbow trout and channel catfish, carp has high ability of digesting its feed ingredients, especially plant sources.

\section{Carbohydrate Feeds}

Corn, wheat and starch are primarily used as energy sources. Also in Israeli carp these energy sources showed high carbohydrate ADC ranging about from 90 to $110 \%$. The ADC values of protein in starch were meaningless since the protein contents of corn starch and gelatinized starch were found to be 1.43 and $0.74 \%$, respectively. The ADC values of amino acids in starches were not calculated as the contents of amino acids in these ingredients were of non-detectable amount.

The ADC values of starch appeared to be good in carp irrespective of whether it be gelatinized or non-gelatinized starch. Chiou and Ogino (1975) found that common carp were able to digest about 85 percent of the starch when it made up from 19 to 48 percent of the diet. The 


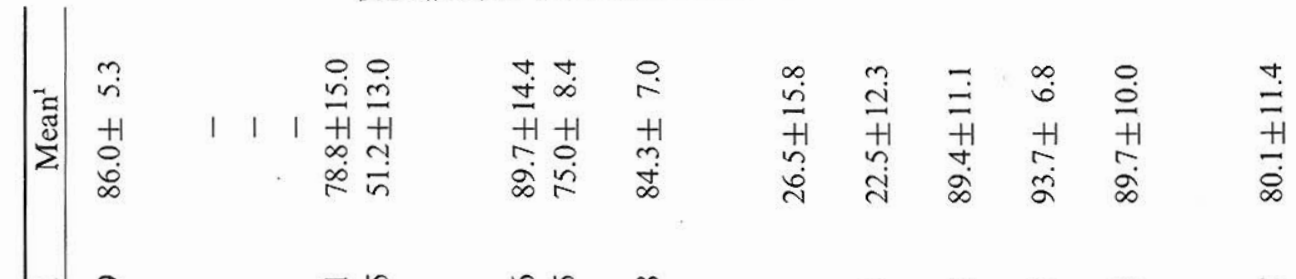

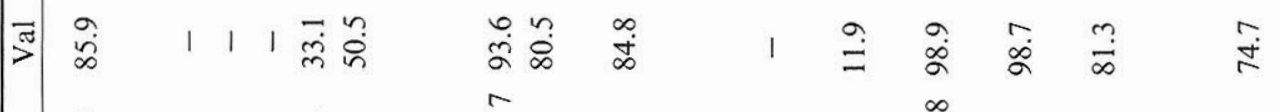

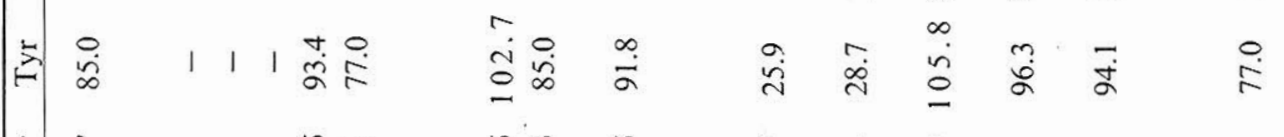

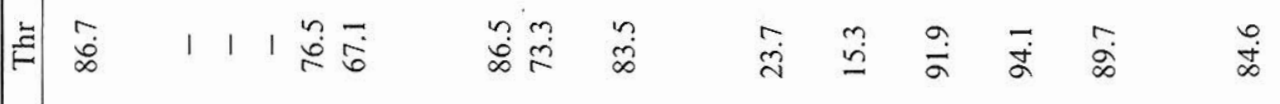

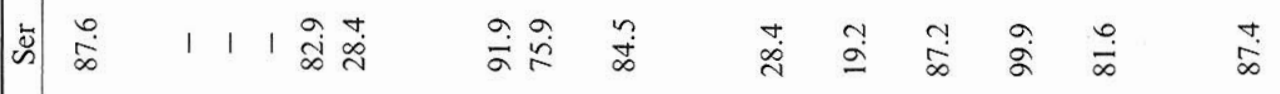

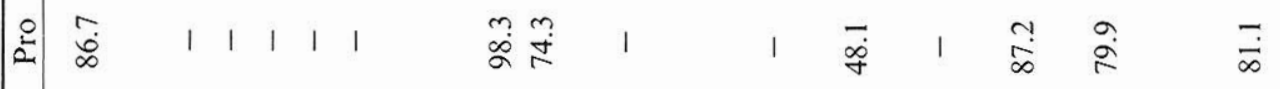

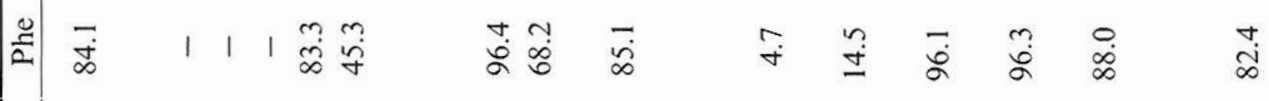

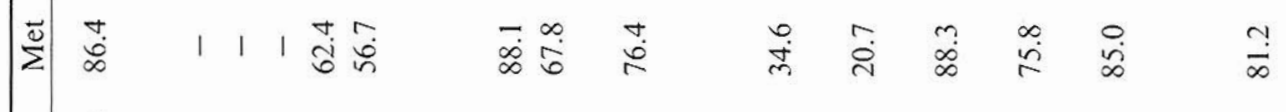

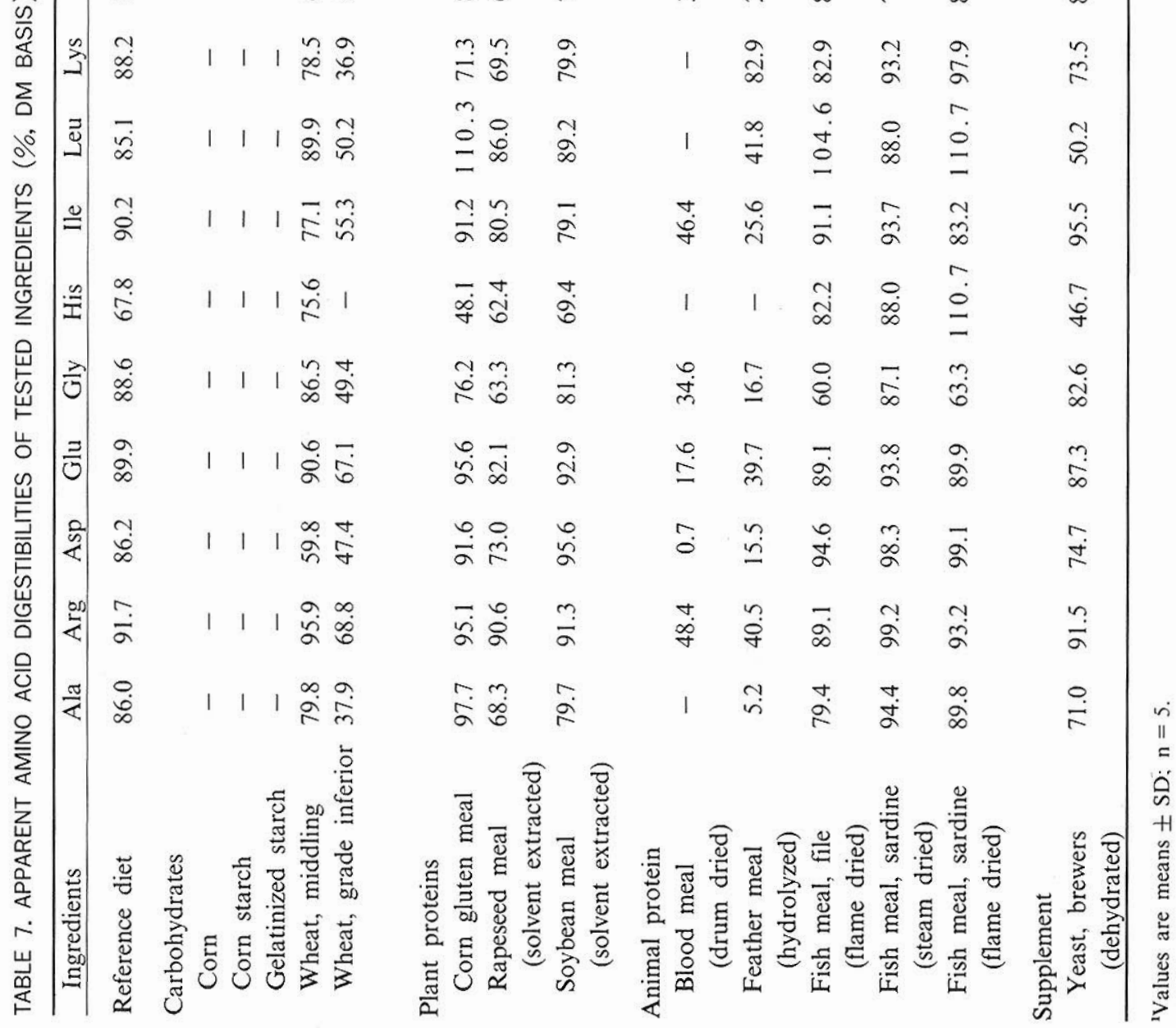


ADC of wheat middling for tilapia was reported to be $75.6 \%$ in protein and $57.6 \%$ in energy (Hanley, 1987) whereas in case of rainbow trout it was $92 \%$ in protein and $40.1 \%$ in energy (Cho and Slinger, 1979).

\section{Plant Protein Feeds}

The ADC of most protein feedstuffs of plant sources resulted in as high values as animal protein sources. This result might supply a basis for the idea of substituting high cost fish meals with relatively low cost plant proteins. In recent years, there has been much interest in the possibility of using various protein sources, especially plant proteins as a replacement for fish meal in producing fish feed. Many of the results obtained so far have proved encouraging in rainbow trout (Cho et al., 1974) and grass carp (Dabrowski and Kozak, 1979) and common carp (Viola et al., 1981), etc.

The high ADC values of protein and amino acids of CGM supported the assumption that CGM was a kind of good protein sources to Israeli carp if supplemented properly with essential amino acids, especially lysine. The low DMD of rapeseed meal may probably due to high fiber contents and high level of complex carbohydrates such as gluconapin, glucobrassicanapin, glucobrassicin, neoglucobrassicin, napoleiferin and progoitrin, etc. (Hilton and Slinger, 1986). The DMD of soybean meal (solvent extracted) was much lower than expected $(45.3 \%)$ and it was much similar to the digestibility for trout $(43.6 \%)$ than carp (83.7\%) reported by Atack et al. (1979) using hand stripping method. The protein digestibility of soybean meal (solvent extracted) has been reported to be high enough (approx. 85\%) in channel catfish (Lovell, 1977), rainbow trout (Smith, 1976) and tilapia (Popma, 1982).

\section{Animal Protein Feeds}

Most animal protein sources appear to be highly digestible by Israeli carp. Some of the variation that has been reported may have resulted from the manner in which the feedstuffs were processed prior to being evaluated (Atack et al., 1979). The proportions of nutrients in the diet have an effect on digestibility. Page and Andrews (1973) indicated that decreased protein digestibility occurred in channel catfish when the diet had high levels of carbohydrates. The feeding value of fish meal is said to be varied somewhat according to the method of drying and the type of raw materials used (Ensminger and Olentine, 1978; Won and Han, 1990). The method of drying may be either vacuum, steam of flame dried. The older flame drying method exposes the product to a higher temperature. This makes the proteins less digestible and destroys some of the vitamins. However in this experiment the method of drying showed no significant difference in digestibility. The fish meal made from sardine, resulted in high overall ADC irrespective of drying method. Concerning to the raw materials used, the fish meal can be made from the offal produced in fish packing or canning factories or from the whole fish, and also it may be changed according to species. The result of this experiment showed that this difference also existed. The fish meal made from file fish (flame dried) showed much lower ADC values than expected. This could be explained partly by the high ash content $(26.6 \%)$ in the file fish meal as previously reported by Nose and Mamiya (1963) and Gulley (1980).

\section{Supplement}

Brewers yeast (dehydrated) is an excellent source of highly digestible protein with good quality. It can replace up to $80 \%$ of the animal protein content of swine and poultry rations when properly supplemented with calcium (Ensminger and Olentine, 1978). Though yeasts are classified as supplements in carp ration, its higher ADC shows that it can be also used as good dietary protein source.

Digestibility values of 14 feedstuffs have been obtained from Israeli carp in this experiment, however, more data concerning DE values and nutrients availabilities of feed ingredients should be acquired effectively for the purpose of formulating Israeli carp (Cyprinus carpio) diet.

\section{Acknowledgements}

This experiment was performed by the financial support of The Korea Science and Engineering Foundation. 


\section{Literature Cited}

Atack, T. H., K. Jauncey and A. J. Matty. 1979. The utilization of some single cell proteins by fingerling mirror carp (Cyprinus carpio). Aquaculture 18:337348.

AOAC. 1990. Official Methods of Analysis, 15th ed. Arlington. VA.

Chiou, J. Y. and C. Ogino. 1975. Digestibility of starch in carp. Bull. Jpn. Soc. Sci. Fish 41:465-466.

Cho, C. Y., H. S. Bayley and S. Y. Slinger. 1974. Partial replacement of herring meal with soybean meal and other changes in a diet for rainbow trout (Salmo gairdneri). J. Fish. Res. Board Can. 31: 1523-1528.

Cho, C. Y. and S. J. Slinger. 1979. Apparent digestibility measurement in feedstuffs for rainbow trout. Proc. World Symp. on Finfish Nutrition and Fishfeed Technology, Hamburg 20-23 June, 1978. Vol. II. Berlin.

Dabrowski, K. and B. Kozak. 1979. The use of fishmeal and soybean meal as a protein source in the diet of grass carp fry. Aquaculture 18:107-114.

Ensminger, M. E. and C. G. Olentine. Jr. 1978. Feeds and Nutrition. The Ensminger Publishing Co. CA.

Furukawa, A. 1976. Diet in yellow tail culture. In: K. S. Price. Jr., W. N. Shaw and K. S. Danberg, eds. First Int. Conf. Aquaculture Nutrition, Oct. 1975, College of Marine Studies, University of Delaware, Newark, Del.

Gulley, D. D. 1980. Effect of mineral ash content on Atlantic menhaden meal (Brevoortia tyrannus) digestibility by rainbow trout (Salmo gairdneri). J. Col/Wyo. Acad. Sci. 12(1):17.

Hanley, F. 1987. The digestibility of feedstuffs and the effects of feeding selectivity on digestibility determinations in tilapia, Oreochromis niloticus (L.). Aquaculture 66:163-179.

Han, I. K., Y. H. Chiang, L. E. Harris, L. C. Kearl and P. V. Fonnesbeck. 1982. Korean Tables of Feed Composition. Korea Feed Information Center and International Feedstuff Institute.

Hastings, W. H. 1969. Nutritional score. In: O. W. Neuhaus and J. E. Halver, eds. Fish in Research. Academic Press, N. Y.

Hastings, W. H. 1967. Feed formulation, physical quality of pelleted feed: digestibility. In: Progress in Sport Fisheries Research 1966. U. S. Fish. Wildl. Serv., Resour. Publ. 39.

Hastings, W. H. 1966. Progress in sport fisheries research, 1966. Feed formulation: phsical quality of pelleted feed: digestibility. U. S. Bur. Sport Fish. Wildl. Res. Publ. 39:37-141.

Hilton, J. W. and S. J. Slinger. 1986. Digestibility and utilization of cannola meal in practical-type diets for rainbow trout (Salmo gairdneri). Can. J. Fish. Aqua. Sci. 43:1149-1155.

Inaba, D., C. Ogino, C. Takamatsu, S. Sugano and H. Hata. 1962. Digestibility of dietary component in fishes. I. Digestibility of dietary proteins in rainbow trout. Bull. Jap. Soc. Sci. Fish 28:367371 .

Kitamikado, M., T. Morishita and S. Tachino. 1964. Digestibility of dietary protein in rainbow trout. II. Effect of starch and oil contents in diets, and size of fish. Bull. Jpn. Soc. Sci. Fish 30(1):50-54.

Lovell, R. T. 1977. Digestibility of nutrients in feedstuffs for catfish. In: Stickney, R. R., R. T. Lovell, ed., Nutrition and Feeding of Channel Catfish. Southern Cooperative Series pp. 33-37.

Migita, M., T. Hanaoka and K. Tuzuki. 1937. A study of vegetable feedstuffs in fish culture. I. Nutritive value of some polysaccharides. Imp. Fish. Stn. No. 8:99-177.

NRC. 1981. Nutrient requirements of coldwater fishes. National Academy Press. Washing- ton, D.C.

NRC. 1983. Nutrient requirements of warmwater fishes and shellfishes. National Academy Press. Washington. D.C.

Nose, T. 1960a. On the diestion of food protein by goldfish (Carassius auratus L.) and rainbow trout (Salmo irideus G.). Bull. Freshwater Fish. Res. Lab. 10(1):12-22.

Nose, T. 1960b. On the effective value of freshwater green algae, Chlorella ellipsoidea, as a nutritive source to goldfish. Bull. Freshwater Fish. Res. Lab. 10(1)-10.

Nose, T. 1967. Recent advances in the study of fish digestion, pp. 83-94. In: J. L. Gaudet, ed. Symp. Feed. Trout Salmon Cult., Rome, 1967. FAO EIFAC Tech. Pap. No. 3.

Nose, T. and H. Mamiya. 1963. Protein digestibility of flat fishmeal in rainbow trout. Bull. Freshwater Fish. Res. Lab. 12(2):1-4.

Page, J. W. and J. W. Andrews. 1973. Interaction of dietary levels of protein and energy of channel catfish (Ictalurus punctatus). J. Nutr. 103:13391346.

Popma, T. J. 1982. Digestibility of selected feedstuffs and naturally occuring algae by tilapia. $\mathrm{Ph}$. $\mathrm{D}$. Dissertation, Auburn University, Auburn, AL. USA.

Singh, C. S. and T. Nose. 1967. Digestibility of carbohydrates in young rainbow trout. Bull. Freshwater Fish. Res. Lab. 17(1):21-25.

Smith, R. R. 1971. A method for measuring digestibility and metabolizable energy of fish feeds. The Prog. Fish-Cult. 33:132-134.

Smith, R. R. 1976. Metabolizable energy of feedstuffs for trout. Feedstuffs 48(23):16-17.

Smith, B. W. and R. T. Lovell. 1971. Digestibility of nutrients in semipurified rations by channel catfish in stainless troughs. Proc. Annu. Conf. Southeast Assoc. Game Fish Comm. 25:425-459.

Smith, B. W. and R. T. Lovell. 1973. Determination of apparent protein digestibility in feeds for channel catfish. Trans. Am. Fish. Soc. 102(4):831-835.

Tunison, A. V., D. Brockway, J. Maxwell, A. Dorr and C. McCay. 1942. Protein utilization by brook trout, pp. 24-42. In: The nutrition of trout. Fish. Res. Bull. No. 4. U.S. Fish and Wildlife Service, Cortland Hatch. Rep. No. 11. 


\section{CHU ET AL.}

Viola, S., J. Arieli, U. Rappaport and S. Mokady. 1981. Experiments in the nutrition of carp. Replacement of fishmeal by soybean meal. BAMIDGEH. 33(2):35-49.

Wilson, R. P., E. H. Robinson and W. E. Poe. 1981. Apparent and true availability of amino acids from common feed ingredients for channel catfish. J. Nutri. 11:923-929.

Windell, J. T., J. W. Foltz and J. A. Sarokon. 1978.
Methods of fecal collection and nutrient leaching in digestibility studies. The Prog. Fish Culturist 40:51-55.

Won, T. H. and In K. Han. 1990. Effect of species and drying methods of raw fish materials on the growth performance, carcass composition and nutrients availability in Israeli carp (Cyprinus carpio). Kor. J. Nutri. Feed. 14(3):95-102. 